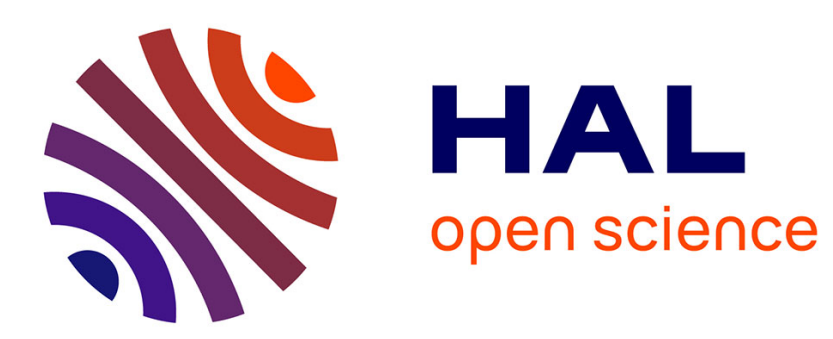

\title{
The Contribution of the Theory of Relation to Knowledge to Understanding Students' Engagement in Learning Physics \\ Patrice Venturini
}

\section{- To cite this version: \\ Patrice Venturini. The Contribution of the Theory of Relation to Knowledge to Understanding Stu- dents' Engagement in Learning Physics. International Journal of Science Education, 2007, 29 (9), pp.1065-1088. halshs-00202087}

\section{HAL Id: halshs-00202087 https://shs.hal.science/halshs-00202087}

Submitted on 5 Aug 2009

HAL is a multi-disciplinary open access archive for the deposit and dissemination of scientific research documents, whether they are published or not. The documents may come from teaching and research institutions in France or abroad, or from public or private research centers.
L'archive ouverte pluridisciplinaire HAL, est destinée au dépôt et à la diffusion de documents scientifiques de niveau recherche, publiés ou non, émanant des établissements d'enseignement et de recherche français ou étrangers, des laboratoires publics ou privés. 
Venturini, P. (2007). The Contribution of the Theory of Relation to Knowledge to Understanding Students' Engagement in Learning Physics. International Journal of Science Education, 29(9), 1065-1088.

\title{
THE CONTRIBUTION OF THE THEORY OF 'RELATION TO KNOWLEDGE' ${ }^{1}$ TO UNDERSTANDING STUDENTS' ENGAGEMENT IN LEARNING PHYSICS
}

\author{
Patrice VENTURINI \\ Université P. Sabatier, Toulouse
}

\begin{abstract}
$\underline{\text { Abstract }}$
The issue of students' engagement in learning physics has generally been analysed in Science Education research using attitudes towards science, or motivation to learn science. However, the corresponding studies have their limitations. Therefore, the object of this paper is to present and to analyse an alternative to these theoretical approaches, namely the 'relation to knowledge', which has been used more and more in the last ten years in French-speaking educational research. The description and discussion of the broad outlines of this theory, of the associated methodology, and of the obtained results regarding the learning of physics, will show the significance of this approach and its limits, as well as the perspectives that it opens up.
\end{abstract}

\section{Introduction}

Student behaviour towards science learning began to be questioned nearly one century ago in the scientists' speeches and the first research on this point is over sixty years old (Bennett, 2001). Yet even if the subject matter is not new, it is of significance today due to the disaffection with scientific studies, which has appeared particularly in physics (Porchet, 2002, p. 45) in several countries. This subject has generally been handled in Science Education research by studying attitudes towards science, and more rarely, by studying motivation to learn science. But, the brief analysis of these approaches mentioned later in this paper shows some of their limits ; this encourages us therefore to look for other theoretical frameworks to better understand and account for the students' engagement in learning science, and more notably, physics. The theory of relation to knowledge, proposed by Charlot (1997), seems interesting in this context since it concerns the students' engagement ${ }^{2}$ in their school work : the question of the relation to knowledge actually arises 'when we note that some individuals, young or adult, want to learn, when others do not want to' (Charlot, 2001, p. 5). This theory, developed fifteen years ago, is used more and more in French-speaking educational research. It is presented here with its associated methodology, and then discussed. In addition, we will examine the results obtained when looking more specifically at learning physics. The latter, described in a synthetic way, also illustrate the use of the theory.

\section{The Limits of Classic Approaches}

The study of attitudes towards science and the analysis of motivation to learn in an educational environment are classic approaches that we can use to understand the degree of 
students' engagement in learning physics. However, even if they lead to some widely accepted results, they have some limits which will now be analysed.

\section{Attitudes towards science}

Many studies about attitudes towards science have been carried out and they are spread out over several decades. They have given rise to many reviews, among which Gardner (1975), Osborne, Simon and Collins (2003), Schibeci (1984) and Venturini (2004). All of them criticize the lack of theoretical references in these works.

Indeed, in a great number of them, the concept of attitude towards science is not explicitly defined, and we need to analyse the method of measurement reported in the methodology to infer a definition, when this is possible. The indicators appearing in these methodological procedures concern science as well as science teaching and the authors study, with nearly similar methods, not only 'attitudes towards' science but also 'relations to' (Boy, 2002), 'views on' (Osborne \& Collins, 2000 ; Rubba, Shoneweg \& Harkness, 1996), 'perception of' (Campbell, 2001 ; Ebenezer \& Zoller, 1993) or 'interest in’ (Dawson, 2000 ; Lindhal, 2003 ; Sjøberg, 2002).

When there is an explicit definition in a paper, it is generally borrowed from Oppenheim (1992, p. 174), for whom an attitude is ' a state of readiness, a tendency to respond in a certain manner [in a positive or negative way] when confronted with certain stimuli', linked to a social object. Though, some rare definitions are more developed (for example, Manassero Más, Vasquez Alonso \& Acevedo Díaz, 2001), the used formulations cannot constitute by themselves a theoretical framework. Only some very rare studies (Coll, Dalgety \& Salter, 2002; Crawley and Black, 1992; Crawley \& Coe, 1990; Lindhal, 2003) use the more elaborate framework of planned behaviour proposed by Ajzen (1987).

This lack of theoretical references has consequences on the investigation methodology. Quantitative in most cases, its aim is to measure an attitude using averages of scores given to various propositions with the help of Likert or Thurstone scales , or of semantic differentiation ones. Then, these measures are used to examine the existence of possible links with other variables (age, gender, matter, etc.). The lack of an established reference leads the researchers to use various tests, involving five to seven items (Breakwell \& Robertson, 2001) to some fifty (Goglin \& Swartz, 1992 ; Weinburgh, 1998 ; Wood, 1998), and this makes the comparison between the results of various studies very difficult. Besides, in the same test, all sorts of indicators are often used, regarding for example the image of science in society, the usefulness of science for a professional career, the pleasure to 'do' science in class, etc. Even if the average of scores given to such various items is an easy way to account for the whole of the answers, it is difficult to give it some significance. Moreover, Gardner detailed at several times $(1975,1995)$ this problem of multi-dimensionality of scales of measurement and its consequences. So, if we suppose that the items have some coherence and allow the researchers to characterize an individual's attitude, the provided results are generally obtained from averages regarding a great number of students ${ }^{3}$, who may be very different, by age, school environment, gender, etc. For that reason, the obtained average represents very global information that hides considerable local disparities. Furthermore, it describes a state, or even its evolution, but it does not indicate anything about the processes that lead to it, which only qualitative studies might bring to light. These studies are very rare (Baker \& Leary, 1995; Osborne \& Collins, 2000; Piburn \& Baker, 1993), even if some quantitative studies use them on a reduced part of the population sample to obtain additional information (for example Ebenezer \& Zoller, 1993; Häussler, Hoffman, Langeheine, Rost \& Sievers, 1998 ; Zohar \& Sella, 2003).

Therefore, even if the very numerous studies on attitudes towards science lead to consensual results (for example, the attitude towards school science being rather negative 
particularly towards physics, attitude degradation with age, boy attitude being better than girl attitude, the impact of the school environment, notably of the teacher and the kind of curriculum etc.), the methodological problems, largely due to a lack of theoretical references, do not fully confirm the validity of the announced conclusions.

\section{Motivation in school environment, the case of science}

The psychology of motivation attempts to explain the causes of behaviour. As behaviour results from the interaction of different factors, the approaches that account for motivation are very different too, most of them handling motivation from a particular point of view (Vallerand \& Thill, 1993). The socio-cognitive approach, which is now often prioritized, bases the motivation study on the interactions between an individual's behaviour, his individual characteristics and those of the environment in which he is placed. These interactions develop on the basis of a reciprocal determinism postulated notably by Bandura $(1986,1997)$. Adopting this point of view, Viau (1994) defines the motivation in education as a student's dynamic state, established from the perception he has of himself and of his environment, which leads him to choose and to do an activity, to persevere in doing it until it is finished in order to reach the goals he has fixed. The socio-cognitive approach, like all the others, has given rise to the formalisation of many theories (Pintrich \& Schunk, 1996), each one being articulated around a very reduced number of factors, influencing motivation, such as the following:

- The kind of pursued goals, as for example, learning and performance goals (Dweck \& Legett, 1987), goals placed in a time perspective (Husman \& Lens, 1999), avoiding work goals (Cosnefroy, 2004), social goals (Furrer \& Skinner, 2003), and so on.

- The value given to an action and the expectancy that it will produce the wanted result (Eccles, Adler, Futterman, Goff, Kaczala, Meece et al., 1983 ; Wigfield, 1994 ; Wigfield \& Eccles 1992).

- The self-efficacy, a notion referring to the perception of one's capacities to carry out an activity with a defined level of performance (Bandura, 1986, 1997).

- The processes of causal attribution that give a meaning to an event, according to the nature of causes assigned to its occurrence (Pintrich \& Schunk, 1996 ; Weiner, 1986).

- The positive or negative emotions produced by a similar activity (Pintrich \& Schunk, 1996, p. 314), but this factor is not unanimously accepted (Viau, 1994, p. 101).

These determinants, some of which suffer from approximate definitions (Pintrich, 2000), are very various. This diversity makes the comparison between the results obtained from different theories very difficult (Boeckaerts, 1999) since they are often very different. Thus, the conceptual split seems to be one of the main characteristics of the works which have been carried out (Cosnefroy, 2004). Even if recent models propose to integrate several of these factors into a whole (Pintrich \& de Groot, 1990; Pintrich \& Schrauben, 1992; Viau, 1994, p. 25), the latter are only juxtaposed, and their interaction, at the root of the motivational dynamics, is simply evoked without being really studied. Yet, 'causal chains rather than simple causes are at the root of motivation' (Williams \& Ivey, 2001). Besides, the studies, an important number of which have been carried out at the primary school level, have dealt with individual variables more than with environmental ones (ibid.), and especially those linked to the school environment. They have also been more focused on the validation of a model which concerns the general mechanisms of behaviour than on the motivation to work in a given discipline. Furthermore, very few studies specific to science do exist: they deal, for example with the influence of some motivational factors on performance (Laukenmann, Bleicher, Fuss, Glaser-Zikuda, Mayring, and Von Rhöneck, 2003; Von Rhöneck, Grob, Schnaitmann, \& Völker, 1998 ; Von Rhöneck et Grob, 1991) or on cognitive engagement (Meece, Blumenfeld, \& Hoyle, 1988 ; Teixera dos Santos \& Mortimer, 2003 ; Zuscho, Pintrich, \& Coppola, 2003), 
or even with the influence of the school environment on motivation (Hanrahan, 1998; Matthews, 2004 ; Meece, 1991). But it is difficult to find unity in these works, because the studies refer to different models, and it is hard to reach conclusions which can be generalized. Lastly, the studies taking into account the students' real voice in all its depth are very rare (Smith et al., 2005, p. 60): they have to be satisfied with expressing their state of motivation through questionnaires and scales focusing on only personal variables connected to a specific model.

\section{Conclusion}

The previous analysis demonstrates the methodological limitations concerning the attitudes towards science studies, mainly because they suffer from a lack of theoretical reference points to guide investigations. The situation is completely opposite for the motivation studies: they have produced a lot of theories, very different one from other, to such a point that we wonder which one we can choose to work with on the question of the student's engagement in his school work. Besides, these studies are rather focused on the student's individual characteristics: the specificities of the disciplines, those of the learned knowledge or those of the learning situations are very rarely tackled in the observed phenomena, which are analysed in a more general way.

This situation has led me to examine another approach in order to work on the question of students' engagement in learning physics, namely the relation to knowledge, proposed by Charlot (1997). This theory has given rise to a large number of works in France and abroad some of which are mentioned in Table 1 . This paper will now specify its theoretical and methodological characteristics.

Table 1. Examples of issues addressed with the theory of the relation to knowledge.

\begin{tabular}{|c|c|}
\hline Issues & Authors \\
\hline $\begin{array}{l}\text { Students' study paths in primary, secondary and } \\
\text { technical schools. }\end{array}$ & $\begin{array}{l}\text { Charlot, Bautier \& Rochex } \\
\text { (1992) Préteur, Constant \& Féchant } \\
\text { (2004) Bautier \& Rochex (1998) } \\
\text { Charlot (1999b) }\end{array}$ \\
\hline $\begin{array}{l}\text { Comparison of pupils', parents' and teachers' } \\
\text { relations to knowledge in primary schools in the } \\
\text { suburbs of Salvador de Bahia. }\end{array}$ & Gauthier \& Gauthier (2001) \\
\hline $\begin{array}{l}\text { Differentiated conceptual evolution regarding } \\
\text { volcanism (primary school) or vegetal production by } \\
\text { photosynthesis (secondary school). }\end{array}$ & $\begin{array}{l}\text { Chartrain (2003) } \\
\text { Catel, Coquidé \& Gallezot } \\
\text { (2002) }\end{array}$ \\
\hline $\begin{array}{l}\text { Links between relations to knowledge and } \\
\text { culture: Tunisian students' differentiated behaviour } \\
\text { when learning the theory of evolution. }\end{array}$ & $\begin{array}{l}\text { Chabchoub (2000) } \\
\text { Hrairi \& Coquidé (2002) }\end{array}$ \\
\hline $\begin{array}{l}\text { Links between relations to knowledge and } \\
\text { written work in philosophy and social science in a } \\
\text { secondary school. }\end{array}$ & Bautier \& Rochex (2001) \\
\hline $\begin{array}{l}\text { Links between the evolution of the relations to } \\
\text { knowledge and the professionalization of trainee } \\
\text { physical education teachers. }\end{array}$ & Jourdan \& Terrisse (2004) \\
\hline $\begin{array}{l}\text { Relation to knowledge and engagement in } \\
\text { research of PhD students in history and mathematics. }\end{array}$ & $\begin{array}{l}\text { Capdevielle-Mougnibas, } \\
\text { Hermet-Landois and Rossi-Neves }\end{array}$ \\
\hline
\end{tabular}


The Relation to Knowledge

\section{Theoretical aspect}

This approach of relation to knowledge has been mainly developed by Charlot, Bautier and Rochex ${ }^{4}$, notably to understand the trajectories which lead (or not) to poor performances at school. Indeed, each human being is confronted with the need to learn a part of the knowledge present in the world (Charlot, 1997, p. 35). Studying an individual in this position, analysing his talk, his behaviour, his personal history etc. to understand what he is experiencing and how he interprets the situation, amount to studying his relation to knowledge.

To learn, the subject must necessarily participate in activities which help in his education process, and become deeply involved. This dynamic originates from a motive, which refers, according to Charlot (1997, p. 63), to desire and also to 'meaning and value'. Saying that an activity has a meaning for somebody is to say that he gives importance and value to it. The meaning appears at the interface between the objective side of the activity (actions and operations) and its subjective side. Of course, for successful learning, the fact that a learning activity has a meaning for the individual and satisfies a desire is not sufficient: the actions that it gives rise to must be effective (Charlot and al., 1992, p. 28).

The previous analysis allows Charlot and al. (1992) to propose a first definition of relation to knowledge:

the relation to knowledge can be defined as a relation to processes (the act of learning), to learning situations and to products (knowledge, as an acquired competence and as an institutional, cultural and social object). It is a relation of meaning and a relation of value: the individual gives value or not to knowledge, according to the meaning he confers on it (p. 29).

Whoever they might be, all the students have a relation to knowledge because 'all the students give and build up a meaning to learning objects and to school situations'. But these relations to knowledge are different according to the individuals and are more or less conducive to learning (Bautier and al., 2000; Bautier \& Rochex, 1998). Charlot (1999b, p. 3) proposes another more descriptive definition:

the relation to knowledge is the organized whole of relations that a human subject, therefore singular and social, maintains with everything regarding in any way, to learning and knowledge: object, thought content, activity, interpersonal relation, place, person, situation, obligation etc., connected in any way to learning and knowledge (p. 35).

Lastly, a third definition reminds us, in a formalized way, that the individual is inseparably singular and social, and uses in order to learn and become a man, the world and the knowledge it contains, the others who help him to learn or prevent him from doing it, and himself: 'the relation to knowledge is a relation to the world, a relation to oneself, a relation to others [...], relation of a singular subject kept in a social space' (Charlot, 1997, p. 91). Because it is a relation to 'processes (the act of learning) and to learning situations', the relation to knowledge has an epistemic dimension: learning concerns neither the same kind of objects nor the same kind of activity, according to different individuals. Because it is a relation to 'oneself', it has a dimension connected with identity: learning takes on a sense with regard to what the individual is and what he wants to become. Finally, it also has a social dimension, which modulates the two previous ones, because learning is an activity that concerns other people, and that is located in a specific social context (Charlot, 1997 p. 87). 


\section{Methodological aspects}

Understanding the individual's relation to knowledge amounts to understanding a singular socially rooted history and to bringing to light the phenomena that, with a constructive plurality, interact in processes leading to establish this relation. These phenomena deal with actions (working at school, at home, often, not at all, etc.), with relations (appreciating the teacher, making their parents happy, etc.), with representations (of school, a subject, a profession, etc.), with motives (expectations, values, etc.), psychic aspects (identifications, projections, etc.), with cognitive and linguistic operations, family, personal events, etc. To identify phenomena and processes, Charlot, Bautier and Rochex (1992) gather data with the help of 'bilans de savoir $^{5}$ ' and interviews.

In their 'bilan de savoir', students have to write the answers at school, to questions such as: 'I am ... years old. I have learnt things at home, at the city, at school, elsewhere. What is really important to me in all this? And what am I expecting from this now?' For the student, then, the question is ' what to talk about, how to talk about it, and what kind of writings to produce' (Charlot and al., 1992 p.134). Indeed, it is impossible for the student to answer by stating everything he has learnt, and one of the method postulates is that students give only the knowledge having the most sense for them. Thus, the 'bilan de savoir' is a tool 'permitting to work on meaning, which is worked out and produced by the student' (Charlot and al., 1992, p. 134), and it is useful in order to understand the individual's relation to learning and knowledge.

Detailed semi-directive interviews are added to the 'bilans de savoir' to identify the phenomena which occur with some frequency for some students. They take place outside the school, last for one hour to one hour and a half, and are aimed at better understanding individuals' singular personal histories. They concern a researcher's posture and a methodology which permit him to gather data but which also try to make the interview a moment of 'clinical work' (though not therapeutic), 'when the subject can, with the help of questioning, of our rewordings and their interpretation effects, discus with himself and question the rationalisation of his own personal history' (Rochex, 1992).

The 'bilans de savoir' and interviews are then analysed in an inductive way, looking for the dominant phenomena and the kind of evoked knowledge, and examining linguistically the way the questions are answered. Research has shown that certain phenomena identified in the 'bilans de savoir' or in the interviews, generally simultaneously appear, permitting the researcher to define 'constellations' of elements, the dynamic interaction of which can be interpreted as a process (Chalot, and al., 1992, p. 41). These constellations are generally presented in an ideal-typical way, the ideal-type ${ }^{6}$ being ' $a$ tool to consider groups and individuals without exhausting their singularity' (Charlot and al., 1992, p. 41). The processes at work are inferred from plausible or proved interactions between different phenomena.

\section{Relation to disciplinary knowledge}

According to Charlot (1999a), even if an individual has a dominant relation to knowledge, this does not prevent him from having different relations with different disciplinary knowledge, which we can study and link to the dominant relation. He also proposes to examine how the relation to knowledge and to disciplinary knowledge makes easier or interferes with the particular knowledge transmission: 'What in the students' relation to knowledge or in the students' relation to a disciplinary knowledge helps or prevents them from understanding what a volcano is, what lightning is, or what the evolution theory is (to understand it according to what science has established)?'. This stance on the existence of a relation to particular knowledge, different from the dominant relation to knowledge, gives the opportunity to study the relations that students have with physics knowledge. These relations will be described after the discussion of the theory and the associated methodology that is mentioned above. 


\section{Discussion}

We can first notice that the relation to knowledge is an interesting concept for science education researchers, since it can be divided, as we have just seen, into relation to physics knowledge, biology knowledge etc. Effectively, these researchers frequently study learning and teaching situations, taking into account the specificities of the concerned disciplinary knowledge. Moreover, this possibility offers the opportunity to link the relation to a particular knowledge to the relation to general knowledge, and it helps in this way to locate the disciplinary learning in the more general context of learning.

Unlike the conceptual split which characterises the motivation theories, the concept of the relation to knowledge has a federative aspect, which can be considered an advantage. Thus, it takes into account the variety of factors taking effect in the act of learning, since it is ' $a$ relation to the world, a relation to oneself, a relation to others' (Charlot, 1997, p. 91). For example, most of the determinants used in the motivation theories (activity value, activity expectancy, self-efficacy, goals, emotions etc.) and most of the factors influencing attitudes (teacher, peers, kinds of activity, gender, etc.) can be taken into consideration with the previous definition of relation to knowledge. Besides, it integrates, as we have seen, the various learning dimensions: epistemic and social dimensions as well as those related to identity. This federative character makes the concept useful and interesting in order to interpret situations and give meaning to them.

As for the methodology created by Charlot and al., it is mainly quantitative and the 'bilans de savoir' and interview analyses are inductive. In this, it is contrary to the majority of attitudes towards science studies and to a number of those about motivation, in which the quantitative part is predominant. The 'bilans de savoir' are a good way to bring together all the factors having effect in the act of learning, and to reveal the elements which have sense for the students. The possibility of making a disciplinary 'bilan de savoir' offers this same opportunity to science education researchers, even if it possible to regret their static aspect ${ }^{7}$. Furthermore, it must be noted that it is necessary to complete them by interviewing some students to obtain more detailed information. When the 'bilans' and interviews are obtained, their analysis can be questioned. It is linked, to some extent, to the researcher's subjectivity, notably to his relation to knowledge (Charlot, 1999b, p. 9). Therefore, even if the inductive analysis has given very interesting results, notably when it is carried out by several researchers, it seems possible to improve the processing of the 'bilans de savoir' and interview data, for example by using a computer process. Though the methodology is now operational, which is a positive point for attitude studies, there is still room for improvement.

There are therefore several important points which arise from this analysis: 1) the federative aspect of the concept of relation to knowledge, 2) the possibility it offers to take into account disciplinary knowledge, 3) its usefulness to interpret situations, 4) the need to improve, if possible, the objectivity of the data processing. This construct, which permits us to understand how and why the student, 'engaged in desire relations, and also in social and institutional relations' (Charlot, 2003), sets (or not) himself up as an epistemic subject in a branch of discipline, seems to be interesting and adapted to tackling the question of the students' engagement in physics learning.

\section{The Relation to Physics Knowledge}

Several studies I conducted or took part in were aimed at analysing the relation to physics knowledge. Among them:

- One of them, in its first part (Venturini, 2005b), revealed the general characteristics of ideal-typical relations to physics knowledge for students from thirteen to sixteen years old ${ }^{8}$. The second part (Venturini, 2005a) revealed the specific characteristics of ideal-typical 
relations of fifteen year old students. It is indeed at this moment that the French students determine the future course of their studies and choose to work mainly on science, economy, technology, or literature etc.;

- Another one (Venturini \& Albe, 2002), carried out with physics and chemistry students in the third university year, concerned the links between the conceptual mastery in a given physics field and the relation to physics knowledge.

We will now look at some meaningful extracts of the obtained results.

General characteristics of the relations to physics knowledge for thirteen to sixteen year old students

The characterisation of the relation to physics knowledge was carried out with 414 students from thirteen to sixteen years old, spread over sixteen classes, using a written 'bilan de savoir': the students were asked about their learned physics knowledge, the importance of that learned knowledge and about how they feel when they are learning physics. Thus, the students answered the following questions: 'what have you learnt in physics since you started studying it? What do you expect to gain from what you have learnt? Is physics very, a little or not at all important for you, and why? With what intention, for what reason do you come to the physics class? When you are in the physics class, would you say that you are engaged in it because you are interested in it, detached because learning physics or something else is quite the same (you have to learn something), or upset, because you would really prefer to be somewhere else?'

The obtained answers were divided into sense units. For example, the answer ' $I$ have learnt electricity and optics' involves, according to the researcher's analysis, two separate ideas and thus, two sense units: 'I have learnt electricity' and 'I have learnt optics'. These sense units were then classified into categories according to their meaning towards the relation to physics knowledge. For example, the two sense units 'I have learnt electricity' and 'I have learnt optics' deal with knowledge in both cases in a general way (physics fields). They were therefore classified in the same category. The whole of the sense units were gathered into thirteen categories. A variable was associated with each of them, and counted for each individual the number of sense units gathered into the category. After this thematic and quantitative analysis, a table was obtained, recapitulating for each student, the distribution of the different sense units of his 'bilan de savoir'. An automatic classification software was used to obtain a hierarchical cluster analysis based on this table; it gathered individuals according to their similarity, calculated from the variable values. The software divided the sample population successively into three, four, five and six classes (groups) and the corresponding contingency tables were elaborated ${ }^{9}$. Every class was characterized with the statistical significant values of the different variables. Dividing the sample population into three or four classes produced too global a result, so it was decided not to use them ${ }^{10}$. On the other hand, the division into six classes provided very little significant differentiation on the level of the relation to physics knowledge, compared to the one comprising five classes. Therefore, this latter was adopted. After that, the statistical significant characteristics of each of its five classes were "idealized" to elaborate the relations of ideal-typical students to which they could be respectively associated:

- the ideal-typical student 1 is strongly engaged in learning physics : he gives great importance to physics knowledge, including outside the school, above all for its contribution to the explanation and comprehension of the world;

- the ideal-typical student 2 is engaged in learning physics in a less marked way than the previous case, with a knowledge focus linked rather to its strategic utility towards his study 
project, even if the world comprehension dimension is not considered completely unimportant;

- the ideal-typical student 3 is weakly engaged in learning physics. For him, physics knowledge is of a weak and episodic importance, essentially for utilitarian and short-term reasons linked to his studies;

- the ideal-typical student 4 gives importance to physics: he attributes meaning to the fact of going to the physics class for mainly utilitarian reasons linked to his future profession or to daily life. However, he does not give any to the knowledge itself, or if he does, it has no effect on his learning;

- the ideal-typical student 5 does not give any importance to physics: neither the discipline, nor the disciplinary knowledge are of importance, and he takes physics courses only because they are compulsory.

To close this first section of results, we can examine the students' distribution ${ }^{11}$ according to the different ideal-types they can be associated to ${ }^{12}$. We can see for example, that physics learning has sense and value only for a minority of students (one out of five). Moreover, the percentage of students associated to the ideal-types 4 and 5, characterized by a lack of engagement in learning physics, regularly increases from 13 to 16 years old. Finally, the majority of students are not very motivated to learn physics, even when science is the main subject at school, notably when they are 16 years old ${ }^{13}$.

\section{Ideal-typical relations to physics knowledge for fifteen year old students}

The second part of the previous study led to the elaboration of more detailed ideal-types, specific to the fifteen year old students. From the previous methodology and classification, we chose, at this level, thirty four individuals, according to the general characteristic of their relation to physics knowledge. They were close to one of the five defined ideal-types. Each one was interviewed for thirty to forty minutes, and first this enabled us to verify which ideal-type they corresponded to most closely. For that, the students had to specify the nature of their relations to physics and its causes, to describe their studying practices in physics as well as in other disciplines, and explain the reasons of their engagement level; they also had to mention their extra-curricular activities involving physics and to evaluate the relevance of physics to understanding the surrounding world. Besides, the aim of the interview was to identify their representations of physics and its social uses, to describe their career plan and its impact on their studies. Finally, questions were asked to identify their perception of the school context in relation to physics: their global stand regarding the teaching discipline and about the teacher's importance in their school work; their opinion about the presence of applicative aspects in the lessons, about the academic character of physics learned knowledge, the answers given to their physics questions; their judgement on the level of their academic success in physics.

The interviews were fully retranscribed and analysed by hand twice to identify the mentioned phenomena ${ }^{14}$ and their modalities. First, the data was processed globally individual by individual, and later, "transversally" for each theme of the interview, to homogenize the way in which the answers of the different students were taken into account. This information was recapitulated in a table making the consistency easier to check, and was used to identify the existing regularities for carrying on the elaboration of the different ideal-types. From the inductive analysis of the interviews, some phenomena appeared in a clear majority of students associated to a same general ideal-type. They were integrated in the corresponding specific ideal-type. Without a clear majority, the phenomenon was ignored. The five obtained idealtypes are described below:

- the ideal-typical student 1 gives importance to physics knowledge because it allows him to understand the world and this is exactly what he expects from it, but also because it is 
useful for the studies he wants to follow. His interest and his work in physics are not linked to the teacher to whom he gives very little importance. He connects what he learns in the physics courses to daily phenomena and applications, and he uses it outside school. Furthermore, he is satisfied with the physics teaching, and would be more so, if he could have more explanation about his questions. He has a developed representation of how physics works and of its social function, but he gives no importance to it. His career plan strongly involves physics, and this makes him more interested in this discipline, in which he feels successful.

We can imagine some processes which combine these phenomena to give this particular relation to knowledge. For example, this student, who tries to understand the world around him, finds at school elements related to daily life and knowledge he can use outside the school, which will satisfy his desire; his career plan requires studies in physics in which he feels successful, and this reinforces his positioning towards the discipline. Thus, these phenomena have effects that strengthen each other: the engagement they lead to will probably be steady.

- The ideal-type student 2 gives importance to physics knowledge, more owing to its strategic usefulness for the studies he wants to follow than for the explanations it brings about the world. He does not give very much importance to the teacher, because the activities related to physics learning are the result of a personal choice. According to him, the lessons would be far more interesting if they included much more daily phenomena. Besides, he considers that the learned knowledge is not very usable outside the school, but this aspect is not important for him. He asks questions directly connected to the lessons and he is satisfied with the answers given by the teacher; he has the feeling that he succeeds in his physics studies. He knows nothing whatsoever about the working methods of physics and about its social function, but he does not give any importance to these facts. His career plan requires studies provisionally including physics.

This student is engaged because he has to succeed in studies including physics to apply for a job without physics. His engagement will surely be temporary: indeed, this student does not use the learnt knowledge outside the school, has no representation of the social use of physics and does not perceive links between lessons and daily facts. For him, physics has only an academic meaning.

- When the ideal-typical student 3 gives a little importance to physics knowledge, it is only for the short-term utility it has in his current studies: indeed, he has no career plan that requires physics studies, and his interest in this discipline, for which he only remembers the broad outlines, is weak. To increase it, on the other hand, he relies very much on the teacher to whom he gives great importance. He does not identify the daily phenomena present in the lessons and finds the learnt knowledge unusable outside school: this contributes to disengaging him. He is ignorant of the working of physics and its social function.

Physics is, at all levels, unfamiliar to this student, and if there is not a charismatic teacher, all the processes we can imagine from the previous phenomena are weakly motivating: occasionally, he could be interested in one topic, or need to improve his average mark.

- The ideal-typical student 4 gives importance to physics ${ }^{15}$ because he finds it useful. He feels engaged in his physics lessons and enters the classroom with an intention to learn, but when interviewed, he never specifies what he wants to study. However, this intention or feeling has no significant effect on how effective a learner he is, even if he strongly expects physics knowledge to be useful for his daily life or for his profession. He finds that the physics lessons sufficiently involve concrete examples, and that the learnt knowledge is not purely academic. He knows nothing whatsoever about how physics works and about its 
social function, but he does not give any importance to these facts. His career plan includes to a small degree, disciplinary knowledge.

For this student, physics makes sense in his daily life or in his career plan, and he finds therefore reasons to engage himself. However, this does not imply that he will be an efficient learner. This student, who does not name learned knowledge in his 'bilan de savoir', or only in a very vague way, says he is engaged and wants to learn, but under no circumstances, does it lead to efficient actions concerning learning.

- The ideal-typical student 5 considers that physics has no importance. He does not expect anything from the learned knowledge: he comes to the physics lessons because he is obliged to and he is not very engaged. He attributes a strong importance to the teacher whose passion and pedagogical qualities could make him like and understand physics. He finds the physics teaching complex, abstract, boring and too fast, and it does not suit him. He does not connect the lessons' content to daily phenomena, and for him, he cannot use outside school the knowledge he learns, and in this way, the discipline loses its interest. He knows nothing whatsoever about the working methods of physics and about its social function and this deprives him of a possible source of interest. He has no questions about this disciplinary subject. His career plan involves neither physics nor physics studies, in which he feels unsuccessful.

Beyond the hypothetical action of the teacher, all other evoked phenomena (for example no operational knowledge, poor performance at school, complex and boring teaching, uselessness of physics knowledge for future profession etc.), contribute to the lack of student engagement, whatever the way we suppose these phenomena interact. For that reason, this situation has little chance of changing.

\section{Relations between relation to physics knowledge and conceptual mastery}

After a study about the basic concepts of electromagnetism used by students ${ }^{16}$ in the third year of university (Venturini, Albe \& Lascours, 2000), twelve individuals were selected, notably because of their level of conceptual mastery in this physics field, to be interviewed for about forty minutes. They had to answer questions which allowed us to characterize relations to physics knowledge and relations to electromagnetism knowledge: the type of learning judged as the most important; the place of physics in that important learning; the knowledge about the nature of physics, function and tools; the interest in daily physics (reading, science history, news, science museums, etc.); daily physics practice (explanations about daily electromagnetic phenomena); study practice (when, how, with whom, etc. does the student study?); relations between the career plan and physics studies (why is the student on a teaching degree? Has he already got teaching experience acquired by giving private lessons or leading a science club etc.); students' electromagnetism perception as a scientific field and as a field of university study. The interviews were fully retranscribed and analysed by hand in an inductive way.

The analysis (Venturini \& Albe, 2002) shows that the students having a weak conceptual mastery, who are in a very large majority in the population sample, learn physics without being able to precisely define its function, its tools and its working methods, and without being interested in it. Even if one of the interviewed students thinks about becoming a physics teacher, it is rarely the result of a deliberate choice, linked to the discipline. They do not look to complete their training outside their university studies, and within this training, they only try to grasp what they judge essential: to be able to solve exercises to pass their exam. For them, this competence involves knowing formulas and solving processes that they possibly learn by heart. The students' relations to electromagnetism knowledge of which they remember hardly anything are difficult: the field of study is abstract, daunting, and badly perceived; applications are not identified, and as a field of study, it has for these students only a utilitarian interest. As 
for the more established conceptual mastery students, although they are not basically very different from the previous ones, they have a more coherent representation of the discipline and of its working, and have some rare extra-school physics activities. Though their aim is still to know how to solve physics exercises for the exam, they try more to understand the elements permitting them to find the solving processes than to learn them by heart, and they get some pleasure out of studying the discipline. Their electromagnetism knowledge allows them to explain the field applications with near exactitude, but all do not grasp the scientific importance of the study.

We can say that the first students have a relation with the disciplinary knowledge, and notably with the electromagnetism, which is dominated by a strictly utilitarian component: they are only moved by short-term school aims. Engaged as little as possible, they try to acquire processing skills to solve exercises without being interested in the concepts' meaning, their relations, and the physics meaning of mathematics tools; this explains why they have been identified as having a weak conceptual mastery. The other students have a relation to physics knowledge which is also characterised by a utilitarian component, but this is modulated by the desire to understand, and the pleasure they get out of this. This desire and this pleasure lead to a greater search of meaning when they try to master the processes of solving exercises; they also lead to the development of skills which gives them a medium or strong conceptual mastery. So, this study reveals links between electromagnetism conceptual mastery and the relation to the disciplinary knowledge, notably because of the students' posture which can be associated to the studies.

\section{Discussion}

First of all, the discussion will concern the importance of the individual when physics learning is studied and the relevance of the theory of relation to knowledge which takes the individual into account. Then, the discussion will focus on the used methodology and the obtained results.

On a very general level, we can notice the usefulness of taking into account the subject's specificities when we are interested in the physics knowledge learnt by students. Indeed, the nature of what is learnt seems to depend on the way the students consider the knowledge at stake, and on the learning posture which follows from that: this can be seen with the example of the basic concepts of electromagnetism, and other studies have illustrated it with the examples of the theory of evolution (Hrairi \& Coquidé, 2002), volcanism (Chartrain, 2003) and the vegetal production by photosynthesis (Catel, Coquidé \& Gallezot, 2002). This need to take into consideration a multi-dimensional subject in the Science Education research is not yet highly emphasized, even if it has been discussed in other articles (for example Alsop an Watts, 2003; Caillot, 2001; Pintrich, Marx and Boyle, 1993; Strike and Posner, 1992).

The previous results also show the advantage of using the relation to knowledge concept when aiming to take the learning subject's specificities into account. Indeed, the method linked to the use of this theoretical framework leads to the development of different ideal-types: these consider the student's engagement to learning physics as a result of a complex process within which various phenomena (some of which have been identified) interact in a plural and constructive way.

It is important to remember that the works on attitudes towards science have analysed the influence of factors considered as independent one from the other for an often large group of students. In addition, a lot of studies on school motivation have been carried out prioritizing a particular and single point of view. Another advantage of the used method is to connect theses phenomena and processes to particular types of students. Indeed, there are practically as many readings and personal interpretations of the different concerned phenomena as there are individuals. Therefore, it is quite difficult to capture in a class, each student in his singularity. 
The definition of a sufficient number of ideal-types to which each student can be associated is a less ambitious but sufficient way to understand the classroom reality and to allow the teacher to adapt himself to his public.

As for the methodology, it is strongly drawn from that proposed by Charlot and his research team, based upon 'bilans de savoir' and interviews. However, it differs on several points.

First of all, the questions of the 'bilans de savoir' in my research are specifically focused on the physics knowledge; they are more numerous so as to be easier to work on. Besides, to be more objective, the analysis of the students' answers was carried out with a classification process by computer. Nevertheless, the students often gave very brief answers to the questions they were asked, which made them difficult to interpret. On the other hand, the regrouping of sense units according to their signification, which were counted within variables analysed by the software, remain linked to the researcher's interpretations. It is the same for the choice of the number of classes that the software gave in order to determine the defined ideal-types. Admittedly, the process can be improved; however, the general characteristics of the relations to knowledge that it allowed me to elaborate seem to have a certain generality. Thus, Rhodes and Venturini (2006) showed that literary students who have compulsory physics lessons in their studies can be associated with the same general ideal-types, except with the ideal-type 1 , which was absent from the sample. Another study (Costa, 1995) analysed American students' responses to school science at the end of the high-school using interviews and led to similar conclusions. Costa elaborated a typology close to the one previously described. Thus, she distinguished the types 'potential scientist', 'other smart kids' (who do not choose to study science), 'I don't know' students (who have no particular position towards school science), and 'outsiders' (who fail in the science class and are outside the mainstream), which can be respectively linked to the general ideal-types $1,2,3$ and 5 . The last type she gave prominence to ('Inside Ousiders') shows partial similarities with the general ideal-type 4.

As for the interviews, they are really important, especially when the answers to the 'bilans de savoir' are brief. Not only do they give the researcher the opportunity to ask the students to talk for longer, but they also lead them to think about the rationality they give to their own story, which is indispensable to understanding their relations to physics knowledge. Yet, the issues about the interview analyses and their objectivity still remain. In the study previously quoted, the interviews were examined twice, firstly individual by individual, and secondly theme by theme. Although the crossing of results probably reduces the subjectivity, we also can imagine other processes to improve the methodology, for example turning to several researchers working in an independent way, or using a textual analysis software.

Beyond these improvements in the processing of the interviews, we also need to enrich the themes the students have to speak about. For the moment, not all the phenomena concerned have been analysed, particularly the gender and the school context. A better knowledge of the impact of the various components of this context, differentiated according to the students' types, would moreover be interesting, since it is an environment on which we can partly act. Nevertheless, the analysis of the elaborate ideal-types, even when incomplete, has led to several observations.

We can first of all notice the importance of the utilitarian component of the relation to physics knowledge in several of the ideal-types previously described, even at university. Of course, we can suppose that all students also go to school because they think it is useful for them. But the importance of the utilitarian component for physics students seems to be specific, if we judge from analysis carried out in other disciplines. For example, Rossi-Neves, Préteur and Capdevielle-Mougnibas (2005) show that the relation to biology knowledge involves a strong hedonistic component, and moreover, that literature and human science students have important expectations concerning general culture. It seems that students are generally working 
in physics with a view to career openings, or to be successful in their studies and obtain their degree. Therefore, it is the school or professional utility which is the essential motive of their activity. This observation echoes with other studies of the same type: thus, for Osborne and Collins (2000), the value of most scientific subjects is purely instrumental, constituted by the academic degree students can obtain; for Munro and Elson (2000), the obligation to learn science in order to accede to the chosen career is the only reason for which young people would study science, and particularly physics (Lindhal, 2003).

We can also notice, in one of the presented studies, the weak ratio of engaged students for learning physics (students associated to the ideal-types 1 and 2) in the population sample. This observation seems to have a more general significance, if we believe another study carried out with French students starting at university on the initiative of the higher education ministry (MENESR, 2005). Indeed, this study shows that medical and physical education students are much more numerous to be engaged in their studies (60\%) than science students $(24 \%)$. Moreover, in the studied population sample, we can notice that the ratio of students who are not engaged in physics learning (students associated to the ideal-types 4 and 5), increases from thirteen to sixteen years old. This observation allows us to think that the situation towards the engagement in physics learning deteriorates with time, as, to some extent, certain studies about attitudes towards science have already shown.

In other respects, we can also notice that students associated to the ideal-types 2, 3 and 5 do not establish connections between learnt knowledge and daily phenomena or events. Even if it is a question of ideal-types, and if all real students who can be associated to one of them do not necessarily have this perception, this trend is sufficiently general to be noted, even in the case of many university third year students who have a strictly utilitarian relation to knowledge. To that, we can add the lack of knowledge that most of them have about the working methods and social use of physics (secondary students associated to the ideal-type 2, 3, 4 and 5, first group of university students). This lack has already also been highlighted by other studies (Cleaves, 2005; Hill \& Wheeler, 1991): physics is a discipline which is often perceived as purely academic, both because students do not transfer the school learnt knowledge in daily life and because they have a very poor representation about its social use. These observations can probably be connected, on one hand to the weak ratio of engaged students the discipline generates, and on the other hand, to the essentially utilitarian reasons which push students to engage in physics studies.

Finally, we can underline the strong teacher importance for students associated to the ideal-types 3, 4 and 5, who are not strongly or significantly engaged in physics learning: it is as if the teacher is the only chance for them of having any kind of engagement. But the necessary teacher qualities change according to students. Besides, the nature of the relation to physics knowledge and to its teaching is an important factor for most of the students associated to the ideal-types 3 and 5: the teacher must be passionate about his discipline and his job. Moreover, for non-engaged students (associated to the ideal-type 5), his pedagogical qualities are determinant.

\section{Conclusion}

The previous analysis shows that the use of the "relation to knowledge" theory, specific to educational science, allows us to better understand the classroom reality and to avoid a part of the problems which appeared during the use of theories of motivation or attitude towards physics while working on the question of the students' engagement in learning physics. This concept highlights the influence of the individuals' particularities on the learnt knowledge, and not only those of the characteristics of the knowledge at stake and of the teaching situations specificities. The existence of previously demonstrated results in studies which used other theoretical frameworks testifies to the operating character of the theory of relation to 
knowledge and also strengthens each different research paradigm. This theory also gives an idea of the processes leading to various engagement types, and reveals the phenomena which constitute them, specific to the different student groups. However, even if the methodology associated to relation to knowledge is operational, it remains to be improved on two levels: firstly for the data gathering process, to obtain more significant information, and secondly for the processing, to obtain better results than with the inductive analysis. Though this gave usable results, it certainly could be more objectified.

To continue such studies, we could for example analyse the evolution in time of the relation to physics knowledge, and possibly identify the prominent phenomena in this evolution, or compare, for a same individual, the relation to physics knowledge with the relations to other disciplinary knowledge, notably to verify if the utilitarian component is really specific to physics. We could continue, of course, the still very incomplete analysis of the phenomena which have effects on the relation to knowledge, or study the teacher's relation to knowledge and how they are connected to the students' one, insofar as some echoes have been observed between these two parties.

Thus, the study of the relation to physics knowledge constitutes an interesting alternative to the works about motivation in science or about attitudes towards science in order to understand the behaviour of students towards learning physics. This approach, which completes the previous ones in order to attempt to interpret a complex reality, is very new but promising; so, it seems sensible and necessary to carry on with it.

\section{References}

Ajzen, I. (1987). Attitudes, traits and actions: dispositional prediction of behaviour in personality and social psychology. In L. Berkowitz (Ed.), Advances in Experimental Social Psychology (Vol. 20, pp. 1-63). San Diego: Academic Press.

Alsop, S., \& Watts, M. (2003). Science education and affect. International Journal of Science Education, 25(9), 1043-1047.

Baker, D., \& Leary, R. (1995). Letting girls speak out about science. Journal of Research in Science Teaching, 32(1), 3-27.

Bandura, A. (1986). Social foundation of thought and action: a social cognitive theory. Englewood Cliffs, NJ: Prentice-Hall.

Bandura, A. (1997). Self-efficacy: the exercise of control. New York: W. H. Freeman and Company.

Bautier, E., Charlot, B., \& Rochex, J. Y. (2000). Entre apprentissage et métier d'élève : le rapport au savoir. In A. Van Zanten (Dir.), L'école, l'état des savoirs (pp. 179-188). Paris: La Découverte.

Bautier, E., \& Rochex J. Y. (1998). L'expérience scolaire des nouveaux lycéens. Démocratisation ou massification ? Paris: Armand Colin.

Bautier E. \& Rochex J-Y. (2001). Rapport au savoir et travail d'écriture en philosophie et sciences économiques et sociales. In B. Charlot (Dir.), Les jeunes et le savoir, pp. 133154. Paris : Anthropos

Bennett, J. (2001). Science with attitude: the perennial problem of pupils' responses to science. School Science Review, 82 (300), 59-70.

Boekaerts, M. (1999). Motivated learning : studying student-situation transactional units. European Journal of Psychology of Education, 14(1), 41-55.

Boy, D. (2002). Les européens, la science et la technologie. Echos d'un sondage. RDT info, March 2002.Bruxelles : Direction Générale Recherche de la Commission Européenne. 
Breakwell G. M., \& Robertson T. (2001). The gender gap in science attitudes, parental and peer influence: changes between 1987-88 and 1997-98. Public Understanding of Science, 10(1), 71-82

Caillot M. (2001). Y a-t-il des élèves en didactique des sciences ? Ou quelles références pour l'élève ? In A. Terrisse (Ed.), Didactique des disciplines Les références au savoir (pp. 141155). Bruxelles: De Boeck Université.

Campbell, B. (2001). Pupils' perceptions of science education at primary and secondary school. In Behrendt, H., Dahncke, H., Duit, R., Graber, W., Komorek, M., Kross, A., et al. (Eds.), Research in Science Education - Past, Present and Future (pp. 125-130). Dordrecht: Kluwer Academic Publishers.

Catel, L, Coquidé, M.-L., \& Gallezot, M. (2002). Rapport au savoir et apprentissage différencié de savoirs scientifiques de collégiens et de lycéens : quelles questions. Aster, 35, 123-148.

Capdevielle-Mougnibas, V., Hermet-Landois, I, \& Rossi-Neves, P. (2004). Devenir chercheur : rapport au savoir et engagement dans la recherche des doctorants en histoire et en mathématiques. Pratiques psychologiques, 10, 141-151.

Catsambis, S. (1995). Gender, race, ethnicity and science education in the middle grades. Journal of Research in Science Teaching, 32(3), 243-257.

Chabchoub, A. (2000). Rapport au(x) savoir(s), didactique des sciences et anthropologie. In A. Chabchoub (dir.) « Rapports aux savoirs et apprentissage des sciences », 37-46. Tunis : ATRD.

Charlot, B. (1997). Rapport au savoir: éléments pour une théorie. Anthropos: Paris

Charlot, B. (1999a). Le rapport au savoir. In J . Bourdon et C. Thélot (Dir.), Education et formation: l'apport de la recherche aux politiques éducatives (pp. 17-34). Paris: Editions du CNRS.

Charlot, B. (1999b). Le rapport au savoir en milieu populaire une recherche dans les lycées professionnels de banlieue. Paris: Anthropos.

Charlot, B. (2001). La notion de rapport au savoir : points d'ancrage théoriques et fondements anthropologiques. In B. Charlot, Les jeunes et le savoir, perspectives internationales (pp. 4-24). Paris: Anthropos.

Charlot, B. (2003). La problématique du rapport au savoir. In S. Maury \& M. Caillot (Dir.), Rapport au savoir et didactiques (pp. 33-50). Paris: Faber.

Charlot, B., Bautier, E., \& Rochex, J.-Y., (1992). Ecole et savoir dans les banlieues et ailleurs. Paris: Armand Colin.

Chartrain, J. L. (2003). Rôle du rapport au savoir dans l'évolution différenciée des conceptions scientifiques des élèves. Un exemple du volcanisme au cours moyen 2 (Doctoral dissertation, Paris 5 University, 2003).

Cleaves, A. (2005). The formation of science choices in secondary school. International Journal of Science Education, 27(4), 471-486.

Coll, R. K., Dalgety, J., \& Salter, D. (2002). The development of the chemistry attitude and experiences questionnaires (CAEQ). Chemistry Education Research and Practice in Europe, 3(1), 19-32.

Cosnefroy, L. (2004). Note de synthèse: Apprendre, faire mieux que les autres, éviter l'échec: l'influence de l'orientation des buts sur les apprentissages scolaires. Revue Française de Pédagogie, 147, 107-128.

Costa, V.B. (1995). When science is « another world": relationships between worlds of family, friends, school and science. Science Education, 79(3), 313-333

Crawley, F. E., \& Black, C.B. (1992). Causal modelling in secondary school science students intention to enrol in physics. Journal of Research in Science Teaching, 29, 585-599.

Crawley, F. E., \& Coe, A. E. (1990). Determinants of middle school students' intention to enrol in a high school science : an application of the theory of reasoned action. Journal of Research in Science Teaching, 27(5), 461- 476. 
Dawson, C. (2000). Upper primary boys' and girls' interests in science: have they changed since 1980 ? International Journal of Science Education, 22(6), 557-570.

Dweck, C. S., \& Leggett, E. L. (1988). A social cognitive approach to motivation and personality. Psychological Review, 95 (2), 256-273.

Ebenezer, J. V., \& Zoller, U. (1993). Grade 10 student's perception of and attitudes toward science teaching and School Science. Journal of Research in Science Teaching, 30 (2), 175-186.

Eccles, J., Adler, T. F., Futterman R., Goff, S. B., Kaczala, C. M., Meece, J., et al.. (1983). Expectancies, values, and academic behaviours. In J. T. Spence (Ed.), Achievement and achievement motives (pp. 75-146). San Francisco: W. H. Fremman.

Furrer, S., \& Skinner, E. (2003). Sense of relatedness as a factor in children academic engagement and performance. Journal of Educational Psychology, 95(1), 148-162

Gardner, P. L. (1975). Attitudes to science: a review. Studies in Science Education, 2, 3-41.

Gardner, P. L. (1995). Measuring attitudes to science: unidimensionality and internal consistency revisited. Research in Science Education, 25 (3), 283-289.

Gauthier J. \& De Souza Gauthier L. (2001). Le rapport au savoir comparé d'élèves, de parents et d'enseignants des écoles de périphérie à Salvador de Bahia. In B. Charlot (Dir.), Les jeunes et le savoir, pp. 69-90. Paris : Anthropos

Goglin, L., \& Swartz, F. (1992). A quantitative and qualitative inquiry into attitudes toward science of non-science college students. Journal of Research in Science Teaching, 28 (5), 487-504.

Hanrahan, M. (1998). The effect of learning environment factors on students' motivation and learning. International Journal of Science Education, 20(6), 737-753.

Haussler, P., Hoffman, L., Langeheine, R., Rost, J., \& Sievers, K. (1998). A typology of students' interest in physic and the distribution of gender and age within each type. International Journal of Science Education, 20(2), 223-238.

Hill, D., \& Wheeler, A. (1991). Towards a clearer understanding of student's ideas about science and technology: an exploratory study. Research in Science and Technological Education, 9, 125-136.

Hrairi, S., \& Coquidé, M. L. (2003). Attitudes d'élèves tunisiens par rapport à l'évolution biologique. Aster, 35, 149-163.

Husman, J., \& Lens, W. (1999). The role of future in student motivation. Educational Psychologist, 34(2), 113-125.

Jourdan, I., \& Terrisse, A. (2004). Rapport au savoir et professionnalisation en EPS : trois études de cas à l'IUFM Midi-Pyrénées. Pratiques psychologiques, 10(2), 153-167.

Laukenmann, M., Bleicher, M., Fuss, S., Glaser-Zikuda, M., Mayring, P., \& Von Rhöneck C. (2003). An investigation of the influence of emotional factors on learning in physics instruction. International Journal of Science Education, 25(4), 489-507.

Lindahl, B. 2003. Pupils' responses to school science and technology. A longitudinal study of pathways to upper secondary school (Doctoral Dissertation, Kristanstad University, Sweden). Abstract retrieved November 21, 2005 from http://naserv.did.gu.se/avhand/lindahl.pdf.

Manassero Mas, M.A., Vásquez Alonso, A., \& Acevedo Díaz J. A. (2001). La evaluación de las actitudes CTS. In Avaluaió dels temes de ciencia, tecnologia i societat. Palma de Majorca : Conselleria d'Educació i Cultura del Govern de les Illes Ballears. Spanish translation retrieved November 21, 2005 from http://www.campusoei.org/salactsi/acevedo11.htm.

Matthews, B. (2004). Promoting emotional literacy, equity and interest in science lessons for 11-14 year olds ; the 'Improving Science and Emotional Development' project. International Journal of Science Education, 26(3), 281-308 
Meece J. (1991). The classroom context and student's motivational goals. In M.L. Maher et P. R. Pintrich (Eds.), Advances in motivation and achievement (Vol. 7, pp. 261-286). Greenwich, CT: JAI Press.

Meece, J., Blumenfeld, P. C., \& Hoyle, R. H. (1988). Students' goal orientation and cognitive engagement in classroom activities. Journal of Educational Psychology, 80, 514-523.

MENESR, Ministère de l'Education Nationale de l'Enseignement Supérieur et de la Recherche, (2005). Les bacheliers S: motivations et choix d'orientation après le baccalauréat. Information Note 05-15 of april 2005 from the DEP. Retrieved November 21, 2005 from ftp://trf.education.gouv.fr/pub/edutel/dpd/ni/ni2005/ni0515.pdf

Munro, M., \& Elsom, D. (2000). Choosing science at 16 : The influences of science teachers and careers advisers on students' decisions about science Subjects and Sciences technology careers. NICEC Research Report. Cambridge: Careers Research and Advisor Centre.

Oppenheim, A. N. (1992). Questionnaire, design, interviewing and attitude measurement (New edition). London: Continuum.

Osborne J., \& Collins, S. (2000). Pupil's and Parent's Views of the School Science Curriculum. London : King's College.

Osborne, J., Simon, S. \& Collins, S. (2003) Attitude toward science a review of literature and its implications. International Journal of Science Education, 25(9), 1049-1079.

Piburn, M. D., \& Baker, D. R. (1993). If I were a teacher... qualitative study of attitude towards science. Science Education, 77(4), 393-406.

Pintrich P. R. (2000). The role of goal orientation in self-regulated learning. In M. Boekaerts, P. R. Pintrich \& M. Zeidner (Eds.), Handbook of self-regulation (pp. 451-502). San Diego (CA): Academic Press.

Pintrich, P. R., \& De Groot E. V. (1990). Motivational and self-regulated learning components of classroom academic performance. Journal of Educational Psychology, 82 (1), 33-40.

Pintrich, P. R., Marx, R. W. \& Boyle, R. A. (1993). Beyond cold conceptual change: the role of motivational beliefs and classroom contextual factors in the process of contextual change. Review of Educational Research, 63(2), 167-199.

Pintrich, P. R., \& Schrauben, B. (1992). Student's motivational beliefs and their cognitive engagement in classroom tasks. In J. Meeces \& D. Schunk (Eds.), Students perception in the classroom (pp.149-183). Hillsdale (NJ): Erlbaum.

Pintrich, P. R., \& Schunk, D. H. (1996). Motivation in education: theory, research and applications. Englewood Cliffs: Prentice Hall.

Porchet, M. (2002). Les jeunes et les études scientifiques : les raisons de la désaffection, un plan d'action. Rapport remis au Ministre de l'Education nationale. Retrieved November 21, 2005 from http://www.education.gouv.fr/rapport/porchet.pdf.

Prêteur, Y., Constans, S., \& Féchant, H. (2004). Rapport au savoir et (dé)mobilisation scolaire chez des collégiens de troisième. Pratiques psychologiques, 10(2), 119-132

Rhodes, C. \& Venturini, P. (2006). Analyse du rapport aux savoirs de la physique d'une classe de $1^{\text {ère }} \mathrm{L}$. Communication à la $8^{e}$ Biennale internationale de l'éducation et de la formation. Lyon 11 au 14 avril 2006.

Rochex, J. Y. (1992). Entre activité et subjectivité: le sens de l'expérience scolaire. (Doctoral Dissertation, Paris 8 University).

Rossi-Neves, P., Preteur, Y., \& Capdevielle-Mougnibas, V. (2005). Filles et garçons vont-ils à l'université pour les mêmes raisons ? L'exemple des filières Lettres et Sciences Humaines. In Proceedings of Questions de pédagogie dans l'enseignement supérieur. Nouveaux contextes, nouvelles compétences. Lille, Ecole Centrale, June 1-3, 2005. 
Rubba, P., Schoneweg, C., \& Harkness, W. (1996). A new scoring procedure for views on Science Technology Society instrument. International Journal of Science Education, 18(4), 387-400.

Schibeci, R. A. (1984). Attitude to science : an update. Studies in Science Education, 11, 26-59.

Sjøberg, S. 2002. Pupils' experiences and interests relating to science and technology. Some results from a comparative study in 21 countries. Retrieved November 21, 2005 from http://folk.uio.no/sveinsj/SLOC\%20Sjoberg\%20paper.pdf.

Smith, C., Dakers, J., Dow, W., Head, G., Sutherland, M., \& Irwin, R. (2005). A systematic review of what pupils, aged 11-16, believe impacts on their motivation to learn in the classroom. EPPI Centre, Institute of Education, University of London. Retrieved November 21, 2005, from http://eppi.ioe.ac.uk.

Strike, K., \& Posner, G. (1992). A revisionist theory of conceptual change. In R. Duschl and R. Hamilton (Eds.), Philosophy of science, cognitive psychology, and Educational theory and practice (pp.147-176). Albany, (NY): State University of New York.

Teixeira Dos Santos, F. M., \& Fleury Mortimer, E. (2003). How emotions shape the relationship between a chemistry teacher and her high school students. International Journal of Science Education, 25(9), 1095-1110.

Vallerand, R.J., \& Thill, E. E. (1993a) (Dir.). Introduction à la psychologie de la motivation. Québec: Vigot.

Venturini, P. (2004). Note de Synthèse : Attitudes des élèves envers les sciences : le point de recherches. Revue Française de Pédagogie, 149, 97-121.

Venturini, P. (2005a). Phénomènes et processus intervenant dans les rapports aux savoirs de la physique : cas d'élèves français en 10ième année de formation. Revue Suisse des Sciences de l'Education, 27 (1), 103-121.

Venturini P. (2005b). Rapports idéal-typiques à la physique d'élèves de l'enseignement secondaire. Didaskalia, 26, 9-32.

Venturini, P., \& Albe, V. (2002). Interprétation des similitudes et différences dans la maîtrise conceptuelle d'étudiants en électromagnétisme à partir de leur(s) rapport(s) au(x) savoir(s). Aster, 35, 165-188.

Venturini, P., Albe, V., \& Lascours, J. (2000). Rapport des étudiants au champ et au flux magnétique. In A. Chabchoub (dir.) ' Rapports aux savoirs et apprentissage des sciences', 175-186. Tunis : ATRD.

Viau, R. (1994). La motivation en contexte scolaire. Québec : Éditions du Renouveau Pédagogique Inc.

Von Rhöneck, C., Grob, K., Schnaitmann, G. W., \& Völker, B. (1998). Learning basic electricity : how do motivation, cognitive and classroom climate factors influence achievement in physics ? International Journal of Science Education, 20(5), 551-565.

Von Rhöneck, C., \& Grob, K. (1991). Psychological aspects of learning in rural and urban classes. International Journal of Science Education, 13(1), 87-95.

Weber, M. (1965). Essais sur la théorie de la science. Paris: Plon.

Weinburgh, M. H (1998). Gender ethnicity and grade level as predictors of middle school student's attitude toward science. In P. Rubba, J. A. Rye (Eds.), Proceedings of the 1998 Annual International Conference of the Association for the Education of Teachers in Science. Minneapolis, Minnesota, January 8-11.

Weiner, B. (1986). An attributional theory of motivation and emotion. New York: Springer Verlag.

Wigfield, A. (1994). Expectancy-value theory of achievement motivation : a developmental perspective. Educational Psychology Review, 6(1), 49-78.

Wigfield, A., \& Eccles, J. (1992). The development of achievement task values: a theoretical analysis. Developmental Review, 12, 265-310. 
Williams S. R. \& Ivey K. M. C. (2001). Affective assessment and mathematic classroom engagement: a case study. Educational Studies in Mathematics, 47, 75-100.

Wood, M. S. (1998). Science-related attitude and effort in the use of educational software by high school students. Unpublished senior thesis, Centre for Educational Technologies, Wheeling Jesuit University, Wheeling, WV. Abstract retrieved November 21, 2005 from http://www.cet.edu/research/papers/attitudes/attitudes.pdf

Zohar, A., \& Sela, D. (2003). Her physics, his physics : gender issues in Israeli advanced placement physics classes. International Journal of Science Education, 25(2), 245-268.

Zusho, A., Pintrich, P. R. \& Coppola, B. (2003). Skill and will : the role of motivation and cognition in learning of college chemistry. International Journal of Science Education, 25(9), 1081-1094. 
${ }^{1}$ In French, 'le rapport au savoir'.

${ }^{2}$ Charlot uses in French, instead of “engagement”, the word 'mobilisation' which has no equivalent in English. He wants to emphasize the fact that the student "moves himself" to study.

${ }^{3}$ The widest study I know (Catsambis, 1995), concerns 24500 students.

${ }^{4}$ The theory of relation to knowledge has been developed at the University Vincennes Saint Denis Paris 8, within the research team ESCOL whose main participants are Bernard Charlot, Elizabeth Bautier and Jean-Yves Rochex.

${ }^{5}$ A student's personal analysis of what is important for him in all his knowledge.

6 'We get an ideal-type emphasizing unilaterally one or several points of view and connecting a lot of phenomena separately given, diffused and discreet, that we find now in a great number, now in a little number, and in places, not at all, that we organise according to different points of view, unilaterally chosen, to make a homogeneous picture of thoughts. We will find nowhere such a picture in its conceptual purity: it is a utopia' (Charlot and al., 1992, p. 41, quoting Weber, 1965).

${ }^{7}$ The 'bilan de savoir' gives information about the relation to knowledge at a particular moment. To study its evolution, it is necessary to make several successive "bilans".

${ }^{8}$ In the French educational system, physics is a compulsory discipline from twelve to fifteen years old.

${ }^{9}$ Dividing the sample population into seven or more classes seems to be open to criticism, given the fact that the pupils' answers were not very developed.

${ }^{10}$ One of the obtained classes was comprised of only eight students. Thus, one of the others had more than 150 students. The relation to physics knowledge which could be associated to these groups was too general.

${ }^{11}$ This information is given as an indication, because the population sample has not been chosen to be statistically representative of the whole of the students following this level of studies.

${ }^{12}$ The real students are more or less close to one of the previous ideal-types, to which they can be associated.

${ }^{13}$ When students choose to study scientific subjects, they have above all to learn mathematics, biology, and physical science (chemistry and physics). The study shows that there are only very few students who are truly engaged in learning physics science, even when disciplines are important for the average.

14 The word 'phenomena' is used here according to Charlot's meaning, as was explained previously.

${ }^{15}$ He gives importance to physics, but not to physics knowledge; even when he gives a degree of importance to knowledge, this does not lead to effective and durably steady learning.

${ }^{16}$ These students were enrolled on a course leading to the competitive entrance exam to be physics and chemistry teachers. 